\title{
Optimization Of Availability Of Water Spring Debit For Customer In Kolhua Village, Maulafa District, Kupang City
}

\author{
Ramzy GGL Sayonara, Sutirto, Arnoldus Nama \\ \{sayonararamzy@gmail.com, sutirtojatayu@gmail.com,n.arnold.Id@gmail.com\} \\ Politeknik Negeri Kupang, Indonesia
}

\begin{abstract}
Water is a basic need that can support the activities of human life and all living things on earth.. Utilization of water is not only limited to household needs, but also for public, social, and economic facilities. The people of Kolhua Village consist of residents or people from Kolhua Village and the people from the Lopo Indah Permai shelter. Following the results of the analysis, the water discharge needed according to population growth in Kolhua Village, MaulafaSubdistrict, Kupang City is 12.56 liters / second with complete customer service of 6,679 people. An alternative solution to the problems if there is a lack of water discharge to meet the needs of drinking water service customers in Kolhua Village, MaulafaSubdistrict, Kupang City,is that PDAM Kupang in the coming year must add water debit from the spring with a spring discharge of 3.56 liters / second.
\end{abstract}

Keywords: Basic water needs, increasing water requirements, trapping surface water flow.

\section{Intruduction}

In the effort to supply clean water, a distribution network is essential because it provides water from production installations to consumers of freshwater, in this case, the community [1]. Regarding the increasing need for clean water in the future, it is necessary to have an excellent freshwater planning system and routine maintenance to ensure customer satisfaction/drinking water services [2].

In Kolhua Village, MaulafaSubdistrict, Kupang City, there is a very densely populated settlement which is increasing year by year and increasing. The people of Kolhua Village consist of residents or people from Kolhua Village and the people from the Lopo Indah Permai residential facilities. The Lopo Indah Permai residential facility was built since 1986 until now where the development of residential facilities is still ongoing. The drinking water facilities used are using water facilities from the Kupang District drinking water company. The source of the spring used comes from a spring in the village of Kolhua. Every year, there is an increase in population.

Following the problem described above, it is necessary to have a study on optimizing the availability of spring water discharges used by the needs of water services in Kolhua Village, Maulafa District, Kupang City.

The problem formulations in this research are:

1. How much water flow is needed in relation to population growth in Kolhua Village, Maulafa

District, Kupang City? 
2. What is the alternative solution to the problem if there is a lack of water discharge to meet the needs of customers of drinking water services in Kolhua Village, Maulafa District, Kupang City?

\section{Research Methodology}

\subsection{Research sites}

The location of this research is in Kolhua Village, Maulafa District, Kupang City, East Nusa Tenggara Province, and is presented on the map below.

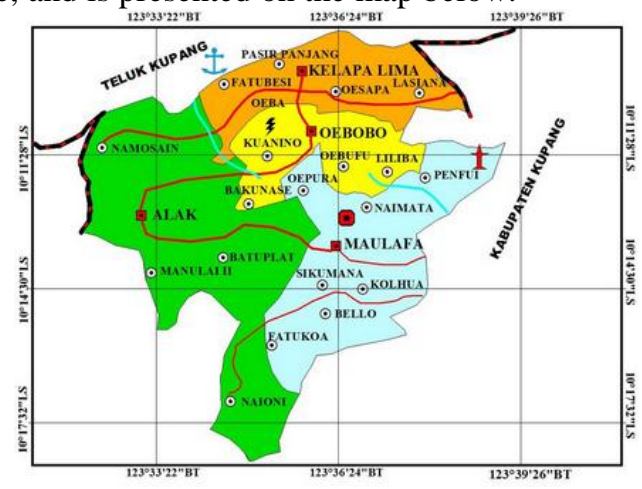

Fig. 1. Research Location

2.2 Flow Chart

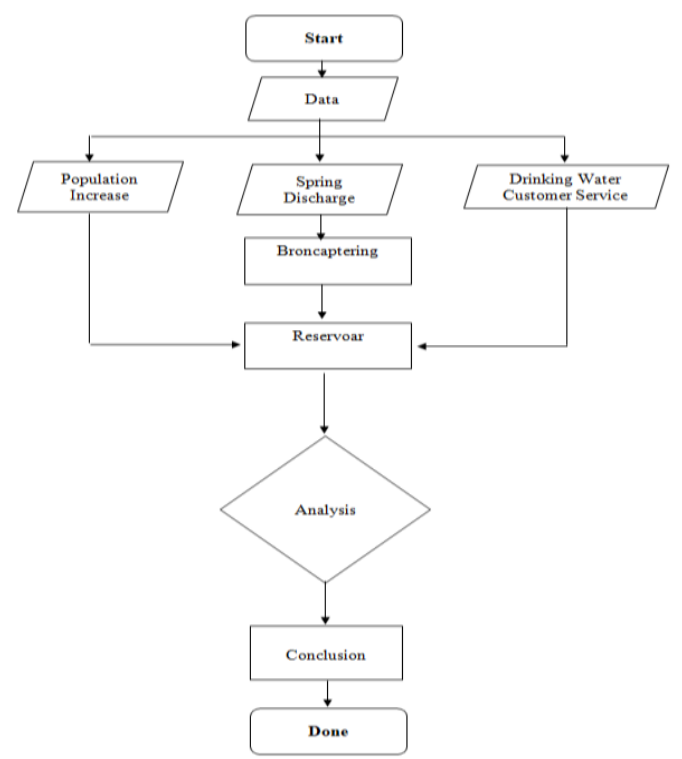

Fig. 2. Research Flow Chart 


\section{Results and Discussion}

\subsection{Calculation of Projection of Population}

\section{Arithmetic Method}

$\mathrm{Pn}=\mathrm{Po}+\mathrm{Ka}(\mathrm{Tn}-\mathrm{To}) . \mathrm{Ka}=\frac{\mathrm{P} 2-\mathrm{P} 1}{\mathrm{~T} 2-\mathrm{T} 1}$

Calculation of Ka value (Arithmetic constant)

Planning Year 2020:

$\mathrm{Ka}=\frac{\mathrm{P} 2-\mathrm{P} 1}{\mathrm{~T} 2-\mathrm{T} 1}=\frac{\mathrm{P} 2010-\mathrm{P} 2010}{\mathrm{~T} 2010-\mathrm{T} 2010}=\frac{6679-6679}{2010-2010}=\frac{0}{0}=0,00$

Planning Year 2021 :

$\mathrm{Ka}=\frac{\mathrm{P} 2-\mathrm{P} 1}{\mathrm{~T} 2-\mathrm{T} 1}=\frac{\mathrm{P} 2011-\mathrm{P} 2010}{\mathrm{~T} 2011-\mathrm{T} 2010}=\frac{6766-6679}{2011-2010}=\frac{87}{1}=87$

Planning Year 2029:

$\mathrm{Ka}=\frac{\mathrm{P} 2-\mathrm{P} 1}{\mathrm{~T} 2-\mathrm{T} 1}=\frac{\mathrm{P} 2019-\mathrm{P} 2010}{\mathrm{~T} 2019-\mathrm{T} 2010}=\frac{8394-6679}{2019-2010}=\frac{1715}{9}$
$=190.56$

Obtained Arithmetic equation:

Planning Year 2020 :

$\mathrm{Pn}=\mathrm{P} 0+\mathrm{Ka}(\mathrm{T} 2-\mathrm{T} 1) .2020=\mathrm{P} 2010+0.00(2020-2019)=6,679+0.00(2020-2019)=$ $6,679+0.00(1)=6,679$ people.

Planning Year 2021 :

$\mathrm{Pn}=\mathrm{P} 0+\mathrm{Ka}(\mathrm{T} 2-1) .2021=\mathrm{P} 2011+87(2021-2019)$

$=6,766+87(2021-2019)=6,766+87(2)=6,940$ people

Planning Year 2029 :

$\mathrm{Pn}=\mathrm{P} 0+\mathrm{Ka}(\mathrm{T} 2-\mathrm{T} 1) .2029=\mathrm{P} 2019+190.56(2029-2019)=8.394+190.56(2029-2019$ )$=8.394+190.56(10)=10,299.6$ people.

Further calculations can be seen in Table 1 below.

Table 1. Population Projection by the Arithmetic Method

\begin{tabular}{|c|c|c|r|}
\hline No & Year & $\mathrm{Ka}$ & $\begin{array}{c}\text { Total } \\
\text { Population }\end{array}$ \\
\hline 1 & 2010 & 0 & 6,679 \\
\hline 2 & 2011 & 87 & 6,766 \\
\hline 3 & 2012 & 131.5 & 6,942 \\
\hline 4 & 2013 & 181 & 7,222 \\
\hline 5 & 2014 & 200.75 & 7,482 \\
\hline 6 & 2015 & 183 & 7,608 \\
\hline 7 & 2016 & 176.83 & 7,774 \\
\hline 8 & 2017 & 160 & 7,802 \\
\hline 9 & 2018 & 193.12 & 8,262 \\
\hline 10 & 2019 & 190.56 & 8,466 \\
\hline
\end{tabular}

Source: Calculation Results, 2019 


\subsection{Geometric Method}

Further calculations can be seen in Table 2 below.

Table 2. Population Projection by the Geometric Method

\begin{tabular}{|c|c|c|r|}
\hline No & Year & I & $\begin{array}{c}\text { Total } \\
\text { Population }\end{array}$ \\
\hline 1 & 2010 & 0.0000 & 6,679 \\
\hline 2 & 2011 & 0.0130 & 6,766 \\
\hline 3 & 2012 & 0.0050 & 6,942 \\
\hline 4 & 2013 & 0.0130 & 7,222 \\
\hline 5 & 2014 & 0.0080 & 7,482 \\
\hline 6 & 2015 & 0.0020 & 7,608 \\
\hline 7 & 2016 & 0.0030 & 7,774 \\
\hline 8 & 2017 & 0.0008 & 7,802 \\
\hline 9 & 2018 & 0.0060 & 8,262 \\
\hline 10 & 2019 & 0.0256 & 8,466 \\
\hline
\end{tabular}

Leasts Square Method :

Source: Calculation Results, 2019

$\mathrm{Y}=\mathrm{a}+\mathrm{Bx}$ 
Table 3. Population Projection by Least Square Method

\begin{tabular}{|c|c|c|c|c|}
\hline Year & Year To $(\mathrm{X})$ & $\begin{array}{c}\text { Total } \\
\text { Population } \\
(\mathrm{Y})\end{array}$ & $\mathrm{XY}$ & $\mathrm{X}^{2}$ \\
\hline 2010 & 1 & 6.679 & 6.679 & 1 \\
\hline 2011 & 2 & 6.766 & 13.532 & 4 \\
\hline 2012 & 3 & 6.942 & 20.826 & 9 \\
\hline 2013 & 4 & 7.222 & 28.888 & 16 \\
\hline 2014 & 5 & 7.482 & 37.410 & 25 \\
\hline 2015 & 6 & 7.594 & 45.564 & 36 \\
\hline 2016 & 7 & 7.740 & 54.180 & 49 \\
\hline 2017 & 8 & 7.799 & 62.392 & 64 \\
\hline 2018 & 9 & 8.224 & 74.016 & 81 \\
\hline 2019 & 10 & 8.394 & 83.940 & 100 \\
\hline Jumlah & $\Sigma \mathrm{X}=55$ & $\Sigma \mathrm{Y}=74.842$ & $\mathrm{XXY}=427.427$ & $\Sigma \mathrm{X}^{2}=385$ \\
\hline
\end{tabular}

Source : Calculation Results, 2019

Where:

$\mathrm{Y}=$ the value of the variable is based on the regression line

$\mathrm{X}=$ independent variable

$\mathrm{a}=$ Constant

$\mathrm{b}=$ coefficient of regression direction

Further calculations can be seen in Table 4 below.

Table 4. Leats Square Method

\begin{tabular}{|c|c|c|c|c|}
\hline No & Year & (Constante) & $\begin{array}{c}\text { b } \\
\text { (Linear Regression } \\
\text { Coefficient) }\end{array}$ & $\begin{array}{c}\text { Total Population } \\
\text { (Soul) }\end{array}$ \\
\hline 1 & 2020 & $2.007,10$ & $1.396,92$ & 34.040 \\
\hline 2 & 2021 & $2.349,78$ & $1.445,00$ & 41.752 \\
\hline 3 & 2022 & $1.901,20$ & 977,10 & 13.626 \\
\hline 4 & 2023 & $2.394,10$ & $1.047,50$ & 16.011 \\
\hline 5 & 2024 & $3.232,20$ & $1.167,20$ & 19.573 \\
\hline 6 & 2025 & $4.972,50$ & $1.415,80$ & 26.209 \\
\hline 7 & 2026 & $10.773,80$ & $2.244,60$ & 46.687 \\
\hline 8 & 2027 & $6.464,30$ & $8.529,20$ & 20.963 \\
\hline 9 & 2028 & $8.080,30$ & 448,80 & 16.158 \\
\hline 10 & 2029 & 64,22 & 279,56 & 6.531 \\
\hline
\end{tabular}

Source: Calculation Results, 2019

According to the calculation results of the three methods above, all the results can be seen in table 5 below. 
Table 5. Calculation of Population Using 3 Method

\begin{tabular}{|c|c|c|c|c|}
\hline \multirow{2}{*}{ No } & Year & \multicolumn{3}{|c|}{ Method } \\
\cline { 3 - 5 } & & $\begin{array}{c}\text { Aritmatic } \\
\text { (Soul) }\end{array}$ & $\begin{array}{c}\text { Geometric } \\
\text { (Soul) }\end{array}$ & $\begin{array}{c}\text { Least Square } \\
\text { ( Soul) }\end{array}$ \\
\hline 1 & 2020 & 6.679 & 6.679 & 34.040 \\
\hline 2 & 2021 & 6.940 & 6.943 & 41.752 \\
\hline 3 & 2022 & 7.336 & 7.011 & 13.626 \\
\hline 4 & 2023 & 7.946 & 7.507 & 16.011 \\
\hline 5 & 2024 & 8.486 & 7.721 & 19.573 \\
\hline 6 & 2025 & 8.692 & 7.670 & 26.209 \\
\hline 7 & 2026 & 8.978 & 7.880 & 46.687 \\
\hline 8 & 2027 & 9.079 & 7.842 & 20.963 \\
\hline 9 & 2028 & 9.962 & 8.626 & 16.158 \\
\hline 10 & 2029 & 10.299 & 10.811 & 6.531 \\
\hline
\end{tabular}

Source: Calculation Results, 2019

From the results of the recapitulation calculations in table 10above, the method used for the next calculation reference is the method that has greatest number of population projections, which is the Geometric method, where the total population projection in 2029 is 10,811 people

\subsection{Calculation of Clean Water Needs}

\section{Domestic Water Needs (D)}

Calculation of the domestic sector is a critical aspect in calculating future supply needs [3]. Calculation of the domestic sector for the future is carried out based on the estimate of population growth in the planned area. Based on the standard clean water requirements and clean water planning criteria listed in table 2.1. up to table 2.4. On pages 11-13 of Chapter II, the residents of Kolhua Urban Village are classified in the Small Town category with a population of 10.811 people and water use of $130 \mathrm{Lt} /$ person/day and the population served is $80 \%$ of the total population.

Domestic Water Needs (D)

$\mathrm{D}=\mathrm{Pn} \times \mathrm{Pa} \times \mathrm{Tp}$

Where:

$\mathrm{D}=$ Domestic Water Needs (L / sec)

$\mathrm{Pn}=$ Number of Population (soul)

$\mathrm{Pa}=$ Use of Water $=130$ liters $/$ person $/$ day $(\mathrm{T}$ abel 2$)$

$\mathrm{Tp}=$ Level of Services $=80 \%($ Table 22. P.1 3 ) 
Domestic water needs are as follows:

Planning Year2020 :

$\mathrm{D}=6679 \times 130 \times 0,80=694616$ liter/per day

$$
\begin{aligned}
& =\frac{694616 \text { liter }}{24 \times 60 \times 60 \text { second }}=8,03953 \text { liter } / \text { second } \\
& =0,00803953 \mathrm{~m}^{3} / \text { second }
\end{aligned}
$$

Planning Year2021 :

$\mathrm{D}=6943 \times 130 \times 0,80$

$=722072$ liter/day

$=\frac{722072 \text { liter }}{24 \times 60 \times 60 \text { second }}=8,3573$ liter $/$ second

$=0,0083573 \mathrm{~m}^{3} / \mathrm{second}$

Planning Year 2029 :

$\mathrm{D}=10.811 \times 130 \times 0,80$

$=1.124 .344$ liter $/$ day

$=\frac{1124344 \text { liter }}{24 \times 60 \times 60 \text { second }}$

$=13,01324$ liter $/$ second $=0,01301324 \mathrm{~m}^{3} /$ second

So, the domestic water demand for the 2029 planned year is 13,01324 liters / second = $0.01301324 \mathrm{~m}^{3} /$ second.

\section{Non-Domestic Needs (ND)}

Non-Domestic Needs are assumed to be $25 \%$ or $30 \%$ of domestic needs [4]. In this calculation $25 \%$ is used as follows:

$\mathrm{ND}=25 \% \times \mathrm{D}$

Planning Year2020 :

where:

ND $=$ Non-Domestic Water Needs

$\mathrm{D}=$ Domestic Water Needs= 8,03953 liter/second

Non-domestic water needs as follows:

$\mathrm{ND}=25 \% \times \mathrm{D}$

$=0,25 \times 8,03953$ liter/second

$=2,00988$ liter $/$ second $=0,00200988 \mathrm{~m}^{3} /$ second

Planning Year2021 :

where:

ND $=$ Non-Domestic Water Needs

$\mathrm{D}=$ Domestic Water Needs = 8,3573 liter/second

Non-domestic water needs as follows:

$\mathrm{ND}=25 \% \times \mathrm{D}$

$=0,25 \times 8,3573$ liter/second

$=2,089325$ liter $/$ detik $=0,002089325 \mathrm{~m}^{3} /$ second

Planning Year2029:

where:

ND $=$ Non-Domestic Water Needs

$\mathrm{D}=$ Domestic Water Needs= 13,01324 liter/second

Non-domestic water needs as follows:

$\mathrm{ND}=25 \% \times \mathrm{D}$

$=0,25 \times 13,01324$ liter/second

$=3,25331$ liter $/$ second $=0,00325331 \mathrm{~m}^{3} /$ second 
Therefore the demand for non-domestic water for the 2029 planning year is 3.25331 liter / second $=0.00325331 \mathrm{~m}^{3} /$ second

\section{Water Loss (Ka) and Total Water Needs (T)}

Calculation of total needs is based on domestic, non-domestic water needs and water losses. Water loss is assumed to be $20 \%$ of total water requirements [5].

$\mathrm{KA}=20 \% \times \mathrm{T}$, Total needs $(\mathrm{Q})=\mathrm{D}+\mathrm{ND}+\mathrm{KA}$

where:

$\mathrm{KA}=$ water loss. $\mathrm{Q}=$ total needs.

Planning Year2020 :

Total water need as follows:

$\mathrm{Q}=\mathrm{D}+\mathrm{ND}+\mathrm{KA}$

$=8,03953$ liter $/$ second $+2,00988$ liter/second $+0,20 \mathrm{~T}$

$\mathrm{Q}-0,20 \mathrm{~T}=8,03953$ liter/second $+2,00988$ liter/second

$0,8 \mathrm{~T}=10,049$ liter/second

$\mathrm{Q}=\frac{10,049 \mathrm{liter} / \mathrm{second}}{0,8}$

$=12,56$ liter $/$ second $=0,01256 \mathrm{~m}^{3} /$ second

Water loss (KA) as follow:

$\mathrm{KA}=20 \% \times \mathrm{T}$

$=0,20 \times 12,56$ liter/second

$=2,512$ liter $/$ second $=0,002512 \mathrm{~m}^{3} /$ second

Planning Year 2021 :

Total water need as follows:

$\mathrm{Q}=\mathrm{D}+\mathrm{ND}+\mathrm{KA}$

$=8,3573$ liter $/$ second $+2,089325$ liter/second $+0,20 \mathrm{~T}$

$\mathrm{Q}-0,20 \mathrm{~T}=8,3573$ liter/second $+2,089325$ liter/second

$0,8 \mathrm{Q}=10,44$ liter/second

$\mathrm{Q}=\frac{10,44 \text { liter } / \mathrm{second}}{0,8}=13,058$ liter $/$ second

$=0,013058 \mathrm{~m}^{3} /$ second

Water loss (KA) as follows:

$\mathrm{KA}=20 \% \times \mathrm{T}$

$=0,20 \times 13,058$ liter/second

$=2,6116$ liter $/$ second $=0,0026116 \mathrm{~m}^{3} /$ second

Planning Year2029 :

Total water need as follows:

$\mathrm{Q}=\mathrm{D}+\mathrm{ND}+\mathrm{KA}$

$=13,0132$ liter/second $+3,25331$ liter/second $+0,20 \mathrm{~T}$

$\mathrm{Q}-0,20 \mathrm{~T}=13,01321$ liter/second $+3,25331$ liter/second

$0,8 \mathrm{Q}=16,266$ liter/second

$\mathrm{Q} \quad=\frac{16,266 \mathrm{liter} / \mathrm{second}}{0,8}=20,3325 \mathrm{liter} / \mathrm{second}$

$=0,0203325 \mathrm{~m}^{3} / \mathrm{second}$

Water loss (KA) as follow:

$\mathrm{KA} \quad=20 \% \times \mathrm{T}$

$=0,20 \times 20,3325$ liter/second

$=4,0665$ liter $/$ second $=0,0040665 \mathrm{~m}^{3} /$ second 
The rest can be seen in Table 6 below.

Table 6. Analysis of Water Needs

\begin{tabular}{|c|c|c|c|c|c|c|c|c|c|c|}
\hline & & Total & & & & & & & & \\
\hline \multirow[t]{2}{*}{ No } & Year & Population & D & D & ND & $\mathrm{ND}$ & $\mathrm{KA}$ & $\mathrm{KA}$ & QTotal & Q Total \\
\hline & & (Soul) & (ItrSeconan) & (mi3 Secon) & (tit Secon) & (mi3 Seconds) & (tits Secons) & 3iS Secon) & (tit Secon) & (mi3) $3 \mathrm{cecon}$ \\
\hline 1 & 2020 & 6,679 & 8.0395 & 0,0080995 & 2,0098 & 0,000200988 & 2,512 & 0,00251 & 1256 & 0,0125 \\
\hline 2 & 2021 & 6,443 & 8.3573 & 0,0083573 & 2,08932 & 0,00208932 & 2,611 & 0,00261 & 13,058 & 0,0130 \\
\hline 3 & 2022 & 7,011 & 8.4391 & 0,0084391 & 2,10977 & 0,00210977 & 2,635 & 0,00263 & 13,175 & 0,0137 \\
\hline 4 & 2023 & 7,507 & 9.0362 & 0,0093362 & 2,25905 & 0,0025905 & 2,835 & 0,00283 & 14,118 & 0,0141 \\
\hline 5 & 2024 & 7,721 & 9.2937 & 0,0992937 & 2,232344 & 0,00233234 & 2,881 & 0,00288 & 14,407 & 0,0144 \\
\hline 6 & 2025 & 7,670 & 9.2324 & 0,0092324 & 2,3081 & 0,0023081 & 2,885 & 0,00288 & 14,425 & 0,0144 \\
\hline 1 & 2026 & 7,880 & 9.4851 & 0,0048551 & 2,3712 & 0,0023712 & 2,964 & 0,00296 & 14,82 & 0,0148 \\
\hline 8 & 2027 & 7,442 & 9.4394 & 0,0094394 & 2,35985 & 0,00235985 & 2,949 & 0,00294 & 14,74 & 0,0147 \\
\hline 9 & 2028 & 8,260 & 10.3831 & $0,01038381]$ & 2,58827 & 0,00258827 & 3,242 & 0,00324 & 16,23 & 0,0162 \\
\hline 10 & 2029 & 10,811 & 13.0132 & 0,013013132 & 3,25331 & 0,00325331 & 4,066 & $0, \overline{0,04046}$ & 20,332 & 0,0203 \\
\hline
\end{tabular}

Source: Calculation Results, 2019

From the calculations, clean water needs for the Kolhua village for the 2029 planned year are as follows:

a) Domestic Clean Water Needs $=13,01321 / \mathrm{sec}$.

b) Non Domestic Domestic Water Needs

$=3.25331 \mathrm{l} / \mathrm{sec}$.

c) Loss of water $=4.06651 / \mathrm{sec}$.

d) Total Water Needs (Q) $=20,33251 / \mathrm{sec}$. 
Table 7. Relationship between Total Q and Projected Number of Population for the Year 2020 to 2029

\begin{tabular}{|c|c|c|}
\hline & & \\
\hline Year & Total Population (Soul) & Q Total (ltr/secon) \\
\hline 2020 & 6,679 & 12,56 \\
\hline 2021 & 6,943 & 13,058 \\
\hline 2022 & 7,011 & 13,175 \\
\hline 2023 & 7,507 & 14,118 \\
\hline 2024 & 7,721 & 14,407 \\
\hline 2025 & 7,670 & 14,425 \\
\hline 2026 & 7,880 & 14,82 \\
\hline 2027 & 7,842 & 14,74 \\
\hline 2028 & 8,626 & 16,23 \\
\hline 2029 & 10,811 & 20,332 \\
\hline
\end{tabular}

Source: Calculation Results, 2019

\subsection{Dimensioning of the Reservoir}

The reservoir is intended to accommodate the excess water produced when water usage is smaller than the flowing spring and provides water shortages when water usage is greater than the flowing spring water [6]. For a rural water supply system, the reservoir is calculated to hold water that is flowed from the spring for 12 hours [7]. This is because, at night, it is estimated that almost all residents in rural areas do not use water. Total discharge amount ( $Q$ total ) needed for $=12.56$ liters $/ \mathrm{sec}$. In order to obtain the total water requirements for consumers per day are:

$\mathrm{T}=0.01256 \mathrm{~m}^{3} /$ second $\mathrm{x} 12 \times 60 \times 60$

$=542,592 \mathrm{~m}^{3} /$ day

In planning this reservoir, $40 \%$ of the water needs are taken 24 hours ( 1 day).

Then the volume of water in the reservoir

$=40 \% \mathrm{x}$ volume of water in 1 day

$=40 \% \times 542,592 \mathrm{~m} 3=217.04$

To accommodate the total water volume of $217.04 \mathrm{~m} 3$, the reservoir tank planning in Kolhua Village, Maulafa District, Kupang City uses a ratio of 2: 2: 1 (Table 1 ) which is as follows:

Reservoir tub length $\quad=8 \mathrm{~m}$

The width of the reservoir body $\quad=8 \mathrm{~m}$

Reservoir height $\quad=4 \mathrm{~m}$

So the reservoir volume is obtained:

$\mathrm{V}=$ PXLXT

$=8 \mathrm{mx} 8 \mathrm{mx} 4 \mathrm{~m}$ 


\section{Water Availability from the existing Springs and Reservoirs}

The water discharge from Kolhua springs, whose water is taken by the PDAM to meet the needs of drinking water customer services in 2019, is $=9.00$ liters/second (Measurement Results) .

In order to get the total water needs for consumers per day are:

$\mathrm{T}=0.009 \mathrm{~m} 3 / \mathrm{sec} \times 12 \times 60 \times 60$

$=388.80 \mathrm{~m} 3 /$ day

In planning this reservoir, $40 \%$ of the water needs are taken 24 hours (1 day).

Then the volume of water in the reservoir

$=40 \% \mathrm{x}$ volume of water in 1 day

$=0.40 \times 388.80 \mathrm{~m} 3=155.52 \mathrm{~m} 3$

To accommodate the total water volume of $155.52 \mathrm{~m}^{3}$, the reservoir basin planning in Kolhua Village, Maulafa District, Kupang City uses a ratio of 2: 2: 1 (Table 1 ) is as follows:

Reservoir tub length $\quad=7 \mathrm{~m}$

The width of the reservoir body $\quad=7 \mathrm{~m}$

Reservoir height $\quad=3.5 \mathrm{~m}$

So the reservoir volume is obtained:

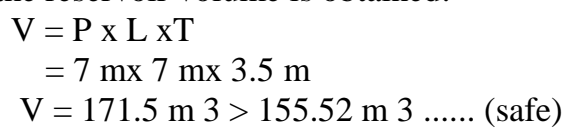

\subsection{Requirements and Availability Analysis}

Water needs to meet the drinking water customer service of Kupang PDAM in 2020 required debit $=12.56$ liters / second with a population of 6,679 inhabitants with reservoir planning that is a building that is intended to accommodate the excess water produced when water usage is smaller than discharge springs that are drained and provide water shortages when water usage is greater than the flowing springs. The results of the calculation of reservoir building planning with length $=8 \mathrm{~m}$, width $=8 \mathrm{~m}$ and height $=4 \mathrm{~m}$ with a storage volume of $=$ $256 \mathrm{~m} \mathrm{3}$. As for the availability of water from springs whose water is taken by the Kupang PDAM, the debit is $=9.00$ liters $/$ second to fulfill the water supply service (resident) of Kolhua Village. The calculation results of reservoir building planning to accommodate a total water volume of $155.52 \mathrm{~m} 3$, reservoir planning length $=7 \mathrm{~m}$, width $=7 \mathrm{~m}$ and height $=3.50 \mathrm{~m}$ with a storage volume of $=171.50 \mathrm{~m}^{3}$.

From the results of the above calculation, Kupang PDAM in serving their customers experiences a shortage, where the total water needed according to the population of 6,679 people requires a spring flow of 12,56 liters / second. The availability of water discharges in the existing spring is of 9.00 liters / second. Accordingly, there is a lack of discharge of 3.56 liters / second.

The reservoir building is intended to be able to serve customers of drinking water services to accommodate excess water that will be flowed from springs for 12 hours at night with water debit of 12.56 liters / second with a total customer service of 6,679 people. $8 \mathrm{~m}$, width $=8 \mathrm{~m}$ and height $=4 \mathrm{~m}$ can accommodate $=256 \mathrm{~m} 3$. As for the results of identification of existing discharge conditions available at the spring is of 9.00 liters / sec. Calculation of reservoir building planning to accommodate a total water volume is of $155.52 \mathrm{~m} 3$, planning reservoir length length $=7 \mathrm{~m}$, width $=7 \mathrm{~m}$ and height $=3,50 \mathrm{~m}$ with a storage volume of $=171.50 \mathrm{~m} 3$ . In accordance with the existing conditions at the moment, the reservoir building will be able water that is accommodated in reservoirs from springs with a discharge of $155.52 \mathrm{~m} 3$ and with the reservoir volume of $450 \mathrm{~m} 3$, water flowed with a turn system that flows on Tuesday and 
Friday ( $4 \mathrm{x}$ in 1 week). The results of the analysis that for Kupang PDAM to meet the service requirements of drinking water customers in 2020, they must add water debit from the spring with a spring discharge of 3.56 liters / second. The reservoir is enough to accommodate the excess water that will be flowed from the spring for 12 hours at night. With this service, 6,679 people will be served every day.

\section{Conclusion}

Based on the analysis results according to the discussion in Chapter $\mathrm{V}$, the following conclusions can be drawn:

1. The required water discharge according to population growth in Kolhua Village, Maulafa District, Kupang City is 12.56 liters / second with complete customer service of 6,679 people.

2. An alternative solution to the problem of lack of water discharge to meet the needs of drinking water service customers in Kolhua Village, MaulafaSubdistrict, Kupang City PDAM Kupang in the coming year must add water debit from a spring with a spring discharge of 3.56 liters/second

\section{References}

[1] Anonim, Babbit, (1989) Water Supply Engineering. Sistem Penyediaan Air Minum. Erlangga, Jakarta

[2] Anonimous, (2012) Depertemen Pekerjaan Umum, Pembangunan Saranadan Prasarana Air Bersih. Bidang Cipta Karya. Kab. Kupang

[3] Naway Ridwan ( 2010), Pengembangan Sistem Pelayanan Air Bersih, Jurnal Fakultas Teknik, Jurusan Teknik Sipil, Universitas Sam RatuLangi, Vol 1 No. 8 Edisi Mei 2010

[4] PEDC Jurusan TeknikSipil ,(1983) Penyediaan Air Bersih, Bandung

[5] Triatmodjo, Bambang, (1985),,Hidrolika I Teknik Pengairan Penerbit Beta offset, Yokyakarta

[6] SularsoHuroaTahara, (1988) Petunjuk Teknis Perencanaan, Pelaksanaan, Pengawasan, dan Pengelolaan Sistem Penyediaan Air Bersih Perkotaan dan Pedesaan (NSPM) Penerbit Ditjen Cipta Karya, Dep. PU, Jakarta.

[7] SusantiRini (2010), Pemetaan Persoalan Sistem Penyediaan Air Bersih unt uk meningkatkan Kualitas Sistem Penyediaan Air Bersih di Kota Sawahlunto, Jurnal Perencanaan Wilayah dan Kota Vol. 21 No. 2 EdisiAgustus 2010 